\title{
PROPOLIS AS A NATURAL FEED ADDITIVE IN RUMINANT DIETS; CAN PROPOLIS AFFECT THE RUMINANTS PERFORMANCE?: A REVIEW
}

\author{
Yosra A. Soltan ${ }^{1 *}$, A. S. Morsy ${ }^{2}$, S. M.A. Sallam ${ }^{1}$, Nesreen M. Hashem ${ }^{1}$ and A. L. Abdalla ${ }^{3}$ \\ ${ }^{1}$ Animal Production Department, Faculty of Agriculture, Alexandria University, Alexandria, Egypt, \\ ${ }^{2}$ Livestock Research Department, Arid Land Cultivation Research Institute, City of Scientific \\ Research and Technological Applications, Alexandria, Egypt, ${ }^{3}$ Laboratório de Nutrição Animal, \\ Centro de Energia Nuclear na Agricultura, Universidade de São Paulo, Piracicaba, São Paulo, Brazil \\ E-mail address: uosra_eng@yahoo.com (Yosra A. Soltan)
}

(Received 3/2/2016, accepted 22/3/2016)

\section{SUMMARY}

$\mathrm{P}$ ropolis is a resinous substance collected by honeybees from buds and leaves of trees and plants, mixing with pollen as well as enzymes secreted by bees. Propolis is known to be active against gram positive bacteria, viruses, fungi, oxidants, inflammation, tumors, and parasites thus recently it have been considered among the natural feed alternative to antibiotics in ruminant diets. Propolis extracts were found to have a promising effect on decreasing energy lost as methane and total $\mathrm{N}$ losses, the most significant inefficiencies remaining in ruminant production systems that may limit production performance and contribute to the release of pollutants to the environment. However, these effects are divers among propolis types. In vitro, however alamo and green propolis were extracted with the same method, but alamo propolis presented a higher efficiency to reduce methane production than the green one and both of them had no effect on ammonia concentrations, gas production and ruminal degradability. Red and brown propolis extracted similarly had very different compositions and seemed to act in a similar way in modifying the ruminal degradation of nutrients and mitigating methane formation. In vivo studies involving ruminant metabolism, divers' effects of different propolis samples have been found on the total digestibility, ruminal digestibility, intestinal digestibility. However, similar effects were observed with the different propolis studies on reducing ammonia production and the number of ruminal ciliate protozoa in buffaloes and dairy cows, as well as in in viro trails. The inhibitory activity of different propolis samples were observed on both mature and immature hepatic worms, and intestinal eggs. Red propolis had good impact on general ewe health during critical periods such as flushing and found to have high efficacy against the gastro intestinal helminthiasis. Similar findings in growth performance in a study on feedlot lambs fed a diet supplemented with brown propolis, but the green propolis was not efficient. Often, in most studies, the type or the chemical composition of the propolis is not even specified in publications. The biological activity of propolis may vary, together with its chemical composition, as it comprises numerous constituents together with the method of extraction and concentrations of the solvent and propolis. Thus in order to ensure the propolis quality as feed additive and to be officially accepted by major health agencies, propolis requires a chemical standardization and identify the active component(s) of propolis and subsequently analyze these in commercial batches.

Keywords: propolis, ruminal fermentation, methane, reproduction.

\section{INTRODUCTION}

The routine use of antibiotics for livestock nutrition has been criticized by consumer organizations and has been restricted recently (Ozturk et al., 2010). As a consequence, several studies have been recently conducted in order to discover other feed alternative additives which considered as natural products that consumers would accept. Recently, propolis extracts have been considered among the natural feed alternative to antibiotics in ruminant diets. Propolis is a resinous natural product with variable colors and consistency collected by honeybees from different parts of plants, such as flower buds, cracks in the bark of trees and leaf buds. Propolis contains more than 300 biochemical constituents, including mostly a mixture of polyphenols, flavonoid aglycones, phenolic acid and their esters, and phenolic aldehydes and ketones, terpenes, sterols, fatty acids, vitamins and amino acids (Park et al., 2000; Alencar et al., 2007 and Morsy et al., 2015).

Propolis always demonstrates considerable biological activity, especially against growth of the gram positive bacteria, antifungal, antiprotozoal and antioxidant, thus it might be a useful additive for modifying microbial fermentation in the rumen. Also, propolis was used in the critical periods of the animal life like flushing, pregnancy and lactating, and to improve productive performance and the animal immunity against intestinal parasites (Park et al., 2000, Sakker and Yang, 2010, Soltan et al., 2014, Aguiar et al., 2014, Morsy et al., 2011, 2013 and 2015).

In different habitats, bees choose different plant species as propolis sources and consequently the chemical composition of this product is highly variable. Furthermore, due to the sticky nature of propolis, 
it cannot be used in its crude form and is therefore often purified by extraction with solvents, which are intended to preserve the polyphenolic fractions (Aguiar et al., 2014). Thus, the type and con-centration of the solvent represent another source of variation in the biological activity of the propolis extracts. All of these reasons may affect the efficient use of propolis as additive to ruminants. The objective of the present paper is to review current knowledge and assess the potential benefits of different propolis types as a natural feed additive to chemical antibiotics for ruminants' diets.

\section{WHAT IS PROPOLIS?}

Propolis is a mixture of a plant product and secretions by honeybees (Apis mellifera). Bees collect a resinous mixture from buds of deciduous trees and from crevices in the bark of coniferous and deciduous trees. Bees wax and the secretions from the bees' mandibular and hypopharyngeal glands are added to this mixture. Propolis is used by the bees to cover hive walls, fill cracks, and embalm invading insects that they are killed (Zhou et al., 2008). Apart from resins, constituting about $50 \%$ of the propolis, and wax, constituting about $30 \%$ of its content, propolis also contains essential oils, pollen and other organic components, constituting, respectively $10 \%, 5 \%$ and $5 \%$ of its content (Górecka et al., 2014).

Etymologically the word "propolis" comes from the Greek, meaning (pro = in defense or for, and polis = city) "in defense of the city (or beehive)". Substances, which are identified in propolis, generally are typical constituents of food and/or food additives, and are recognized as generally recognized as safe (GRAS) substances (Alencar et al., 2007). Propolis has been employed extensively since ancient times. Egyptians benefited from the anti-putrefactive properties of propolis in order to embalm their deads. Propolis was used as an antiseptic and cicatrizant agent by the Greek and Roman physicians.

Recently, numerous studies have proven the propolis activity against gram positive bacteria, viruses, fungi, oxidants, inflammation, tumors, parasites, protozoa and it may act against methanogenesis (Alencar et al., 2007; Aguiar et al., 2014; Morsy et al., 2013 and 2015).

\section{PROPOLIS MAIN COMPONENTS:}

The chemical composition of propolis is intrinsically related to the floristic and ecological characteristics of the environment visited by the bees (Table 1) thus propolis does not have a stable and reproducible chemical composition (Alencar et al., 2007). So far, some 300 compounds have been identified in propolis. The following can be discerned as the basic groups among these compounds:

Table (1). Geographic distribution of propolis with definitions of type, plant origin and main content

\begin{tabular}{|c|c|c|c|}
\hline Propolis type & Geographic origin & Plant source & Major constituents \\
\hline Poplar & $\begin{array}{c}\text { Europe, North } \\
\text { America, no-tropic } \\
\text { regions of Asia, New } \\
\text { Zealand }\end{array}$ & $\begin{array}{c}\text { Populus spp. of section, } \\
\text { Aigeiros, most } P \text {. nigra } \\
L .,\end{array}$ & $\begin{array}{c}\text { Flavones, } \\
\text { Flavanones, } \\
\text { Cinnamic acids and } \\
\text { their esters }\end{array}$ \\
\hline Green type 12 & $\begin{array}{c}\text { Brazil, state of Minas } \\
\text { Gerais }\end{array}$ & Manly Baccaris spp. & $\begin{array}{c}\text { Flavonoids } \\
\text { (Pinobanksin and } \\
\text { kaempferal) }\end{array}$ \\
\hline Alamo type 3 & Brazil, Parana state & - & $\begin{array}{c}\text { Flavonoids } \\
\text { (kaempfeidc and } \\
\text { isosakuranetin and } \\
\text { pinobanksin) }\end{array}$ \\
\hline Birch & Russia & Betula verrucosa ehrth & $\begin{array}{c}\text { Flavones and } \\
\text { Flavanones, but not } \\
\text { the same as polar } \\
\text { one }\end{array}$ \\
\hline Red propolis & Cuba, Brazil, Mexico & Dalbergia spp. & $\begin{array}{l}\text { Iso-flavonoids } \\
\text { (isovlavans and } \\
\text { Petrocarpans) }\end{array}$ \\
\hline Mediterranean & Sicily, Greece, Malta & Cuperssaceae spp. & Di-terepens \\
\hline Pacific & Pacific regions & Macaranga tanarius & $\begin{array}{c}\text { C-prenyl- } \\
\text { falavanones }\end{array}$ \\
\hline
\end{tabular}

phenolic acids, flavonoids, terpenes, lipid-wax substances, beeswax, bio-elements and other components such as vitamins, proteins, amino acids and sugars (Park et al., 2000; Alencar et al., 2007 and Górecka et al., 2014). Assuming that the major compounds are predominantly associated with the biological properties and main activity of propolis, the active components may be found within groups of 
isoflavones and flavonoids that have been reported to be biologically active (Alencar et al., 2007; Morsy et al., 2013 and 2015), within fatty acids, or both. Phenolic compounds constitute the most numerous group of propolis components with respect to the quantity and type. Among them there are phenolic acids, phenolic aldehydes, phenols and their esters, ketophenols, coumarins and others compounds, including eugenol, anethole, hydroquinone, pterostilbene, naphthalene, etc. (Górecka et al., 2014). Another group of chemical compounds present in European propolis are flavonoids. These are substances with multi-phenol character. Flavonoids present in propolis are aglycones of glycosidic substances present in plants. While, collecting propolis, bees secrete $\beta$-glucosidase, which hydrolyzes glycosides of flavonoids to the corresponding aglycones and sugars (Kędzia and Hołderna-Kędzia, 2006). The most abundant compounds of the Brazilian red propolis extract were Isoflavonoids, especialy vestitol and medicarpin (Morsy et al., 2015). Aside from the two basic groups of chemical compounds, phenolic acids and flavonoids based on the content of which it is possible to classify a given propolis as poplar type, there are also terpenes present in it. The content of these compounds in propolis is usually small, it amounts to about $0.5 \%$. Among the terpenes isolated from propolis are monoterpenes, sesquiterpenes and triterpenes.

Furthermore, there is a group of substances present in propolis called plant waxes or lipid-wax substances. Plant waxes are composed of sterols, fatty acids and their esters, especially phenolic acids and glycerol esters (Maciejewicz et al., 1983). Morsy et al., (2015) found that the most important characteristic of the Egyptian brown propolis type is its bioactive hexane fraction, which consists of a high proportion of fatty acids. These make up a higher proportion of the total components than flavonoids, which are still prevalent. In the lipid-wax fraction of propolis saturated hydrocarbons like heptadecane, octadecane, eicosane, tricosane are present, as well as unsaturated hydrocarbons: cholestrilene and eicosene (Kędzia and Hołderna-Kędzia, 2006). Propolis contains a large amount of beeswax, which is composed of esters of higher alcohols and lipid acids, as well as of aliphatic hydrocarbons. The main components of beeswax are myricyl esters of palmitic and cerotic acids, cerotic and melissic acid. Beeswax also contains small amounts of alcohols, lactones, carotenoids, cholesterol esters and flavonoids. Among the flavonoids present in beeswax there is chrysin, which gives this product its specific colour (Kędzia and Hołderna-Kędzia, 2006). Propolis exists in different colors (red, brown, yellow, and green), with the same colored samples from different countries apparently showing a greater resemblance to each other than different colored samples from the one country (Alencar et al., 2007).

\section{PROPOLIS ACTIVITY:}

\section{Effect of propolis on ruminal fermentation and degradation:}

Independent of the type or site of collection, Brazilian red propolis and Egyptian brown propolis were incubated in different concentrations $(125,250$, or $500 \mathrm{~g}$ per $500 \mathrm{mg}$ of dietary dry matter) enhanced in vitro concentrations of acetate, propionate, valerate and total short chain fatty acids (SCFA) (Morsy $e t$ al., 2015), the authors attributed the increase in total SCFA mainly to a massive increase in acetate (the major contributor to SCFA) production by $45 \%$ compared to monensin. The same study confirmed the improvement in the ruminal degradation of the truly degraded organic matter with propolis than monensine. This finding is in agreement with Stradiotti et al. (2004) in an in vivo study of the nutrients digestibility of a diet supplemented with propolis in Holstein steers fed a diet containing $65 \%$ forage and $35 \%$ concentrate as the total SCFA was improved by propolis addition without affecting on the molar proportions of ruminal SCFA. Furthermore, Soltan et al., (2014) used the extract of red propolis as natural alternatives to monensin for a $500 \mathrm{~g}$ Tifton hay (Cynodon spp.) plus $350 \mathrm{~g}$ ground corn and $150 \mathrm{~g}$ soybean meal and they observed an enhancement of the in vitro ruminal degradability of neutral detergent fiber compared with monensine, decreased the ruminal ammonia $\left(\mathrm{NH}_{3}-\mathrm{N}\right)$ concentration, while no effects were found for the individual or the total short chain fatty acids.

In vivo, Lana et al. (2005 and 2007) showed that supplementation of propolis (up to $6 \mathrm{~g} / \mathrm{animal} / \mathrm{day}$ ) did not affect total and individual SCFA concentrations in dairy goats fed a diet of $67 \%$ corn silage and $33 \%$ concentrate. In lactating cows, different concentrations of Brazilian propolis extracts contains different phenolic compounds supplemented to $591.9 \mathrm{~g} / \mathrm{kg}$ corn silage and $408.1 \mathrm{~g} / \mathrm{kg}$ concentrate reduced the dietary crude protein ruminal degradability, ruminal $\mathrm{NH}_{3}-\mathrm{N}$ and increased the intestinal digestibility of crude protein (Aguiar et al., 2014). In this study, the authors reported that the propolis samples were collected form an apiary located within a reserve of eucalyptus (Eucalyptus sp.) plants and surrounded by Baccharis dracunculifolia plants. Another study confirmed a reduction in ruminal $\mathrm{NH}_{3}-\mathrm{N}$ Ozturk et al., (2010) when ethanolic extract of propolis was supplemented to 60 forage: 40 concentrate diet but the authors did not mentioned to any information about the place of propolis collection or chemical composition. 
All these findings indicate that different propolis extracts may enhance the ruminal nutrients degradability, while reduce the deamination of amino acids and/or growth rate of amino acids-fermenting bacteria thus different propolis had similar positive effect on rumen nitrogen metabolism.

\section{Effect of propolis on ruminal methane formation and protozoal count:}

Because of the higher antimicrobial activity of propolis against gram positive than gram negative bacteria, propolis might be a natural useful alternative to antibiotics supplementation for modifying microbial fermentation in the rumen to reduce the loss of energy as methane $\left(\mathrm{CH}_{4}\right)$ (Morsy et al., 2011 and 2015), however until now, only a few reports were found in the literature dealing with the effects of propolis on $\mathrm{CH}_{4}$ emission. Morsy et al. (2011) reported that propolis could be used as a natural alternatives product for monensine and they concluded that green and alamo Brazilian propolis presented a similar reduction on rumen $\mathrm{CH}_{4}$ production without negative effect on rumen gas production and in vitro degradability of organic matter. Both Brazilian red and Egyptian brown propolis extracts in different levels $(125,250$, or $500 \mathrm{~g}$ per $500 \mathrm{mg}$ of dietary dry matter) seemed to combat ruminal methanogenesis and the authors attributed this effect to the antiprotozoal effect of propolis, since protozoa are known to provide hydrogen as a substrate for the methanogens which are at least temporarily ecto- and endosymbiotically associated with them (Morsy et al., 2015). Rumen ciliates contribute to the greater part of ruminal methanogenesis via hydrogen supply to the endosymbiotic and episymbiotic methanogens (Ushida and Jouany, 1996).

Inhibition of protozoa reduces methane release by diverting reducing equivalents from methane to propionate synthesis in the rumen. Soltan et al., (2014) evaluated the dose 10, 100, and $1000 \mu \mathrm{g} / 500 \mathrm{mg}$ dry matter diet response effects of the ethanolic extracts of Moringa (Moringa oleifera) leaves, root bark and red propolis as natural alternatives to monensin for sheep diets on rumen $\mathrm{CH}_{4}$, extracts of Moringa leaves (all doses), root bark at 10 and $1000 \mu \mathrm{g}$ and propolis at 10 and $100 \mu \mathrm{g}$ presented similarity in $\mathrm{CH}_{4}$ reduction with monensin and the authors confirmed the inhibitory effect of all experimental levels of propolis on protozoa count and who concluded that Moringa leaves, root bark and propolis could be used as effective natural intervention to monensin in sheep diets, not only to reduce $\mathrm{CH}_{4}$ production, but also to enhance the ruminal efficiency of dietary nutrient use. It could be concluded from the previous studies that propolis in despite of its color or type can affect the methane formation in indirectly way by their anti-protozoal effect.

\section{Effect of propolis on animal reproduction:}

Due to the high content of propolis in flavonoids, it can affect the reproductive performance of the animals. For females, propolis flavonoids due to their non-polarity or in complex with serum albumin, can pass the plasma membrane and can attach to the cytoplasmic steroid receptor. Accordingly, flavonoids are carried into the cell nucleus to the transcription complex at the genes controlling the expression of estrogen receptors and perhaps also of other proteins participating in the growth reproduction and function of the mammary gland (Morsy 2013). Propolis administration was found to have a good impact on pregnant ewe health and may be a promising feed additive during critical periods such as flushing (Morsy et al., 2013).

For males, it has been demonstrated that propolis provides protection against infertility by improving sperm production, motility, count and quality, and increased the process of steroidogenesis and hence testosterone production. Hashem et al., (2013) observed that the dietary manipulation of ethanolic extract of the Egyptian propolis (150 mg/kg diet) offers an easily applicable measure for improving sexual activity and semen quality (high sperm concentration and viability) and testosterone concentrations of rabbit bucks during hot seasons in the subtropics. This sexual activity improvement was associated with the increasing of high density lipoprotein that has several pivotal biological functions including (1) facilitating transportation of hydrophobic lipid molecules like cholesterol and triglycerides to move within the water-based blood stream; (2) transporting cholesterol into steroidogenic organs such as the adrenal gland, ovary, and testis; and (3) removing the excess molecules of low density lipoprotein (LDL) through the liver (Hashem et al., 2013).

\section{Effect of propolis on blood hematological, biochemical parameters and total fecal egg count:}

Recent studies mentioned to the general improvement of the animals health and immunity that fed propolis. The oral administration of ethanolic extract of Brazilian red propolis to Santa Inês ewes (3 g/ewe/day) during the flushing period increased total leukocytes, total protein and globulin concentrations, while decreased triglycerides, glutamate oxaloacetate transaminase, and glutamate pyruvate transaminase (Morsy et al., 2013). Hashem et al., (2013) found that the dietary ethanolic extract of the Egyptian propolis enhanced hematopoiesis including the number of red blood cells, hematocrite value and hemoglobin concentration. Also, concentrations of blood plasma cholesterol and triglycerides were decreased, while glucose and high density lipoprotein and total antioxidant capacity were enhanced 
by propolis supplementation. Sakker and Yang, (2010) compared the effect of propolis as a natural feed additive $(0.05 \%$ of diet) with the antibiotic Naomycine $(110 \mathrm{ppm})$ to the pre weaned Hanwoo Korean calves (from birth to 90 days), although they found an enhancement of the immunoglobulins ( $\operatorname{IgG}, \operatorname{Ig} \mathrm{A}$ and $\operatorname{IgM}$ ) concentrations of propolis group, but without potential for the growth, feed intake blood biochemical parameters and the authors attributed these results for the low level of the supplementation of propolis. In this study the authors mentioned to the propolis supplementation as a powder, but without and indicators of the propolis type, color, method of extraction or any chemical composition.

Propolis was found to be an effective natural alternative to parasitological drugs to control helminthiasis and to significantly decrease the total fecal egg count (FEC) in grazing Santa Inês ewes sheep (Morsy et al., 2013) using ethanolic extract of red propolis (3 g/ewe/day) during the flushing period. In cattle using alcoholic extract of propolis at $33 \%$ in 20 cattle (12 months) naturally infected with Trichuris sp., Trichostrongylus sp., and Ascaris sp. Which was administered in single dose once or twice a day for three consecutive days and 30 days after the start of treatment, they found an average reduction of $59.7 \%$ in the FEC count between animals receiving treatment and average increase of 63.6 $\%$ in the control animals that did not receive any treatment (Dürrewald et al. 2008). Thus it can be concluded that propolis can enhance oxidative status of the blood plasma, may indicate an activation of the animal's immune that propolis has anti-inflammatory and immune modulatory activities system can modulate lipid and protein metabolism and hepato protective effect of propolis.

\section{CONCLUSION}

The findings suggest that there could be an underlying basic effect of propolis, independent of the type or site of collection on ruminal fermentation, methane formation, degradability, animal reproductive and parasitological performance. However a clear definition of the experimental propolis collection places, environmental conditions, chemical composition, concentrations of the main active components and processing methods for propolis extraction should be reported in the further studies that will use propolis as feed additive to avoid inconsistent results that would create confusion in the literature. In most studies, the propolis material that was used originated exclusively from Brazil or countries that had propolis in sufficient quantity, but in other countries where propolis is only adequate for human consumption, propolis will be limited for animal production. Further wide variety In vitro screening studies are needed to correlate the effects of propolis with its corresponding plants around the bee collection site thus propolis might be used as an indicator to the most promising plants extracts that can be used as feed additives and had the same effect as propolis.

\section{REFERENCES}

Aguiar S.C.D., E. M. De Paula, E. H. Yoshimura, W. B. R. Dos Santos, E. Machado, M. V. Valero, G. T. Dos Santos and L. M. Zeoula (2014). Effects of phenolic compounds in propolis on digestive and ruminal parameters in dairy cows, Revista Brasileira de Zootecnia, 43(4):197-206.

Alencar S. M., T. L. C. Oldoni , M. L. Castro, I. S. R. Cabral, C. M. Costa-Neto, J. A. Cury , P. L. Rosalen and M. Ikegaki (2007). Chemical composition and biological activity of a new type of Brazilian propolis: red propolis. Journal Ethnopharmacology, 113(2): 278-283.

Brasileiro de zootecnia, João Pessoa, PB, 2008. 1 CD-ROM.

Dürrewald M. S., E. C. T. Mello-Peixoto, R. C. Garcia, R. A. Teixeira, E.L. Heinzen, and R.O. Orsi (2008). Utilização da própolis no controle de endoparasitas em bovinos, Anais do $18^{\circ}$ Congresso

Górecka A.K., A. Rzepecka-Stojko, M. Górecki, J. Stojko, M. Sosada and G. Ś. Zięba (2014). Structure and antioxidant activity of polyphenols derived from propolis. Molecules, 19 (1): 78-101.

Hashem N. M., A. Abd El-Hady and O. Hassan (2013). Effect of vitamin E or propolis supplementatin on semen quality, oxidative status and hemato-biochemical changes of rabbit bucks during hot season. Livestock Science, 157, (2) 520-526.

Kędzia B. and E. Hołderna-Kędzia, 2006. The bee products in the nutrition and supplementation. Post Fitoter, 4 (1): 13-221.

Lana R. P. M, M. L. Camardelli, A. C. Queiroz, M. T. Rodrigues, E. C. Eifert, E. N. Miranda and I. C. C. Almeida (2005). Soybean oil and propolis in the diets of dairy goats. Revista Brasileira de Zootecnia, 34 (2), 650-658.

Lana, R. P., M. M. L. Camardelli , M. T., Rodrigues, E. C. Eifert, M. V. M. Oliveira, J. D. Stradiotti and J. S. Oliveira (2007). Soybean oil and propolis in the diets of dairy goats: intake of nutrients and ruminal metabolism. Revista Brasileira de Zootecnia, 36(1): 191-197.

Maciejewicz W., M. Daniewski and Z. Mielniczuk (1983). Gas chromatography-mass spectrometry investigation of propolis. Analysis of $\beta$-steroids. Acta Poloniae Pharmaceutica, 40(1): 251-253. 
Morsy A. S., A. L. Abdalla, Y. A. Soltan, S. M. A. Sallam , K. M. El-Azrak , H. Louvandini and S. M. Alencar (2013). Effect of Brazilian red propolis administration on hematological, biochemical variables and parasitic response of Santa Inês ewes during and after flushing period. Tropical Animal Health and Production, 45 (7):1609-1618.

Morsy A. S, Y. A. Soltan, H. M. Elzaiat, S. M. A. Sallam, S. M. Alencar, H. Louvandini and A. L. Abdalla (2011). Effect of two types of Brazilian propolis extracts on rumen gas and methane production and truly degradability in vitro. Middle East and North Africa Journal of Animal Science, 4 (1): $446-456$.

Morsy A. S., Y. A. Soltan, S. M. A. Sallam, M. Kreuzer, S. M. Alencar and A. L. Abdalla (2015). Comparison of the in vitro efficiency of supplementary bee propolis extracts of different origin in enhancing the ruminal degradability of organic matter and mitigating the formation of methane. Animal Feed Science and Technology, 199 (1): 51- 60.

Ozturk H., M. Pekcan, M. Sireli, and U.R. Fidanci (2010). Effects of propolis on in vitro rumen microbial fermentation. Üniversitesi Veteriner Fakültesi Dergisi, 57 (1): 217-221.

Park Y. K., M. Ikegaki, S. M. Alencar and F.F. Moura (2000). Evaluation of Brazilian propolis by both physicochemical methods and biological activity. Honeybee Science, 21(2): 85-90.

Sarker M. S. K. and C.J. Yang (2010). Propolis and Illite as feed additives on performance and blood profiles of post-weaning Hanwoo calves. Journal of Animal and Veterinary Advances, 9 (21), 2704 2709.

Soltan Y. A., R.C. Lucas, A.S. Morsy, H. Louvandini, and A.L. Abdalla (2014). The potential of Moringa oleifera leaves, root bark and propolis extracts for manipulating rumen fermentation and methanogenesis in vitro, International Symposium on Food Safety and Quality: Applications of Nuclear and Related Techniques IAEA Headquarters, Vienna, Austria, 10-13 November 2014.

Stradiotti Junior D., A. C. Queiroz, R. P. Lana, C. G. Pacheco, E. C. Eifert and P. M. M. Nunes (2004). Effect of the propolis on amino acids deamination and ruminal fermentation. Revista Brasileira de Zootecnia, 33(4):1086-1092.

Ushida K. and J. P. Jouany (1996). Methane production associated with rumen-ciliated protozoa and its effect on protozoan activity. Letters in Applied Microbiology, 23(2):129-132.

Zhou J. H., Y. Li, J. Zhao, X. F. Xue, L. M. Wu and F. Chen (2008). Geographical traceability of propolis by high-performance liquid-chromatography finger prints. Food Chemistry, 108 (2): 749 759. 


\section{البرويوليس كا أحد الاضافات الطبيعيه لعلائق المجترات: هل يستطيع البروبولس التأثير علي أداء المجترات؟ :} استعراض مرجعي

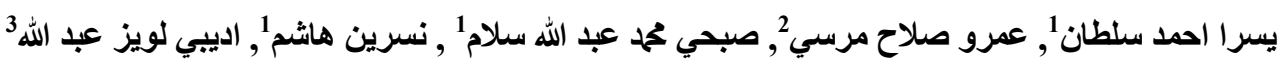
1 2 3 مركز البحوث النوويه الزراعية, جامعة ساوباولو, بيراسيكابا , البرازيل

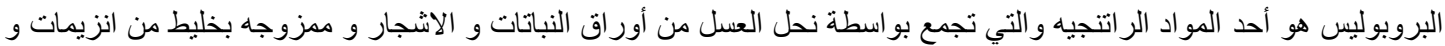

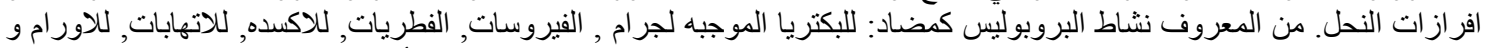

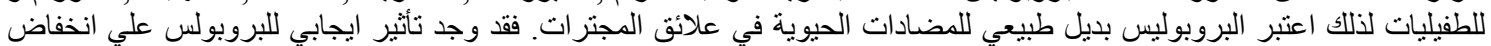

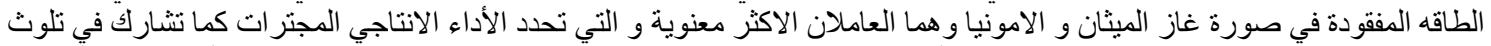

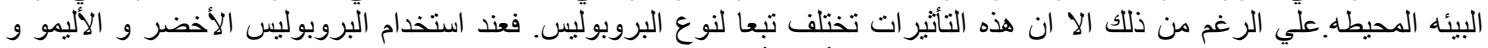

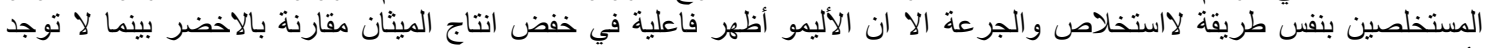

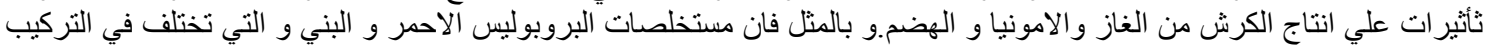

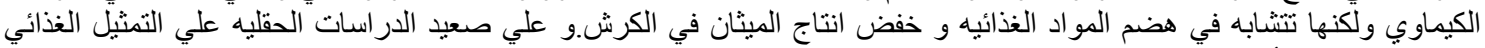

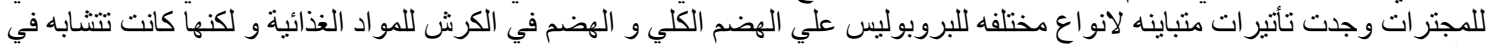

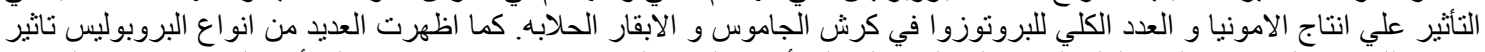

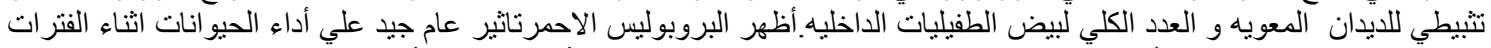

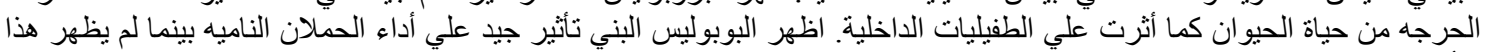

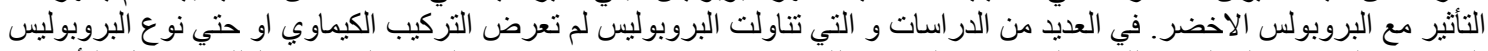

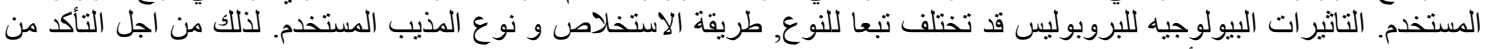

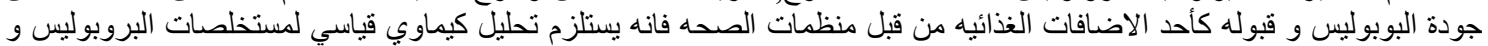
التحديد الكيماوي للمو اد الفعاله. 